\title{
Improving Students' Communicative Competence through Inductive Method Using Authentic Materials
}

\author{
Gede Ginaya \\ Politeknik Negeri Bali, Jl. Kampus Bukit Jimbaran, Kuta Selatan, Badung, Bali, Indonesia \\ Ni Putu Somawati \\ Politeknik Negeri Bali, Jl. Kampus Bukit Jimbaran, Kuta Selatan, Badung, Bali, Indonesia \\ I Nyoman Rajin Aryana \\ Politeknik Negeri Bali, Jl. Kampus Bukit Jimbaran, Kuta Selatan, Badung, Bali, Indonesia \\ I Made Ardana Putra \\ Politeknik Negeri Bali, Jl. Kampus Bukit Jimbaran, Kuta Selatan, Badung, Bali, Indonesia
}

\begin{abstract}
Students were often confused and forced into silence when they communicate in English. This condition became a problem during the teaching-learning process and may eventually lead to poor communicative competence. Inductive teaching method, which employs authentic materials can be a solution to address the aforementioned condition. The objective of this study is finding out the effects of implementing inductive teaching method. using authentic materials, to the students' communicative competence. Participants were 61 fourth semester students ( 22 males and 39 females). enrolled in a three-year diploma program in Travel and Tourism Business Study Program, State Polytechnic of Bali. Data are collected through classroom action-based research procedures. By conducting a quasi-experimental design, the collected data were analyzed by paired t-tests and mixed design ANCOVA. The study reveals the English communicative competence of the students significantly increased, shown by the mean score on the post-test, namely 63.05 in the control group and 84.43 in the experimental group $[t=-23.485, p=.000]$ at the level of $\mathbf{p}<.05$. In addition, their learning motivation and interest also increased as it is shown by the result of the questionnaires. Limitations and suggestions for successful applied action-integrated instruction and implications for future research are provided.
\end{abstract}

Index Terms-inductive method, authentic materials, communicative competence

\section{INTRODUCTION}

The purpose of learning English in vocational colleges such as the Bali State Polytechnic is to make students able to communicate in English correctly and well. Correct means that according to the English grammar method and good means it is in accordance with the norms of manners and hospitality in language, and can use communication strategies. The three components of communicative competence are in accordance with the statements of Canale and Swain (1980, 1981) in Bagarić and Djigunović (2007, p. 97), namely the communicative competency model which contains three main components, namely grammatical, sociolinguistic and strategy competencies. Hymes (Bagarić and Djigunović, 2007, p. 97) and Celce-Murcia (2007, p. 46) state socio-linguistic competence as appropriateness.

Mastery of students' communicative English competence is very important to improve during the teaching and learning process as an effort to produce competent and professional graduates in the field of work to be pursued in the industrial world. The increase in mastery of communicative English competence of students requires innovative learning methods, namely inductive methods and supported with authentic material in the current context (deal with current issues) so that effective, efficient, and contextual learning is created in accordance with the real situation in the industry so that links and match between universities vocating competent HR printers and industry as users. The implementation of innovative learning is carried out through a classroom action-based research (CAR) process.

Research in the field of learning is that the term authenticity has been attempted and applied in an effort to achieve the fundamental goal in the use of language, namely communication (Glaser, 2014). Castilo et al (2017) suggested the relationship between approach and authenticity in language learning as an inductive approach in the process of generalization to draw conclusions about the rules of grammar from various authentic texts. In addition to the inductive approach in language learning, it is also known as a deductive approach. Prince and Felder (2006) state that deductive learning methods are traditional learning with a methodological paradigm that departs from something general to something special. 
The deductive learning method according to the perceptions of educational psychologists is fewer motivating students in learning, because students will have high learning motivation if they are clearly seen in certain knowledge and skills (Prince and Felder, 2006; Balim, 2009; Elison, 2010; Slavin, 2010; Saumell, 2012; Davtyan, 2014; Rodríguez González et al, 2016). Prince and Felder (2007) state that inductive learning methods can be applied in learning foreign languages. According to Prince and Felder, the delivery of general principles to something specific can be done, but is followed by an interpretation of the principle, analyzing a case study or providing a solution to a problem. to do generalizing a rule, procedure, principle directed by the instructor.

The role of teaching material in a learning method as proposed by Richards and Rodgers (2014) is a way to reflect the nature of teaching material, for example the content of material, practicing it, facilitating communication between students, or making students can practice alone without a lecturer guidance. In line with Richards and Rodgers, Castilo (2017) states that teaching material plays a fundamental role in language learning, because teaching materials are used by lecturers to facilitate learning inside and outside the classroom. Kim (2000) and Day (2004), Rogers in Kilickaya (2004), Dorda (2008), Tomlinson (2012), McDonough and Shaw (2012), Polio (2014) define teaching material as something that can be used to facilitate language learning, including textbooks, videos, graded readers, flash cards, games, websites and interactions via event mobile phones though, in fact, most literature centers on printed material.

Learning English with authentic material is carried out by Al Azri et al (2014), Rahman (2014), Belaid (2015), Ghanbari (2015), Carmona (2015), Allehyani et al (2017), Castillo (2017). All of these studies proved that authentic material for motivating students, increasing interest in learning and learning languages according to the real situation. This proposed study is very different. The focus of this study is Tourism which is English ESP, specifically the implementation of inductive methods based on authentic materials to improve communication competence of students in the Tourism Department. Mastery of communicative competence will be very useful for the development of professional human resources (HR) and is very relevant to the concept of green HR development (Syarkawi M: 2015), namely if students are able to communicate in English integratively, not partially between the methods of grammar, socio-linguistics, and communication strategies will create good and positive human resources in providing services in the tourism service industry.

\section{A. Statement of the Problem}

Based on the background above, the problem of this research can be formulated as follows:

1. Is there a significant increase in the posttest score of students' communicative competence in the control and experimental groups?

2. Are there significant differences in the posttest scores of the control and experimental groups with respect to the implementation of inductive methods using authentic material?

\section{B. Research Purposes}

The objectives to be achieved in this classroom action research are to examine the effectiveness of the application of inductive methods and the use of authentic material in improving student communicative competence in the English for Tourism and Event courses as an effort to implement innovative learning to support green human resources development.

\section{RESEARCH METHODS}

\section{A. Research Design}

The design of this study was quasi-experimental by dividing students into experimental and control groups. The experimental group received treatment in the form of giving action with 3 learning cycles. While the control group gets teaching based on the material contained in the previous textbook (Ginaya, 20018: 4).

\section{B. Research Subject}

This research was conducted at the Bali State Polytechnic Tourism Department which involved 4th semester students or at the pre-intermediate level. Participants consisted of 51 students in the Travel Tourism Business Study Program 2019/2020. There were 2 classes in semester 4, namely class 4A with 31 students (11 men and 20 women) as the control group and $4 \mathrm{~B}$ with 30 students (11 men and 19 women) as the experimental group.

\section{Data Collection Technique}

Data were collected based on classroom action research procedures, namely cyclic processes of planning, action, observation, and reflection (Kemmis et al, 2013). Therefore, the research that has been carried out consists of three learning cycles and each cycle is completed in two meeting sessions each week. The application of PTK uses teaching diaries and observation sheets, and other instruments in the form of tests and questionnaires. There are two types of tests used in this study, such as pretest (test 1) for initial observations about the communicative competence of students, posttest (test 2) to determine the ability after treatment is given. The questionnaire is used to collect data, especially those relating to students' feelings, motivations, and interests in the application of inductive methods and the use of authentic material. 


\section{Data Analysis}

Data were analyzed in two ways, namely quantitative and qualitative. Quantitative data were analyzed based on oral presentations during the learning period. The communicative competency value of students on initial observation and pretesting (test 1) was analyzed using the SPSS-17.0 program and t-test to ensure equality between the experimental group and the control group. Meanwhile, student scores in the posttest (test 2) were re-analyzed using SPSS. Then, a sample of parallel t-tests in both groups was calculated to determine the difference between pretest and posttest in each group. To determine the difference in communicative English competence between the experimental and control groups in the posttest, covariance analysis (ANCOVA) was carried out. Meanwhile, qualitative data were analyzed based on the results of observations made after giving the treatment and the results of questionnaire entries.

In this case, the condition and situation of the class during the learning process takes place, the interactions, motivations, attitudes, and interests of students in carrying out the exercises and communicative activities are analyzed to determine the effectiveness of the applied learning model. In addition, to find out the problems that may be faced by students during the teaching and learning process, which causes the communicative competence of English to not increase. Furthermore, the classified data were analyzed by qualitative descriptive method with the basis of the inductive methodological paradigm, namely the presentation of problems from specific to general to reach a conclusion (Ginaya, 2018: 24).

\section{RESULTS AND DISCUSSION}

The data obtained were analyzed in two ways, namely quantitative and qualitative. Quantitative data were analyzed based on the performance of oral presentations during the teaching and learning process. Student scores in the initial observation (test 1 ) were analyzed using the SPSS-17.0 program and t-tests were calculated to ensure the experimental and control groups at the same level of ability. Meanwhile, student scores in the posttest (test 2) were analyzed again using SPSS. Then, the t-test samples in the parallel groups of the two groups were calculated as an attempt to investigate the differences between the pretest and posttest in each group.

The difference in posttest values between the experimental and control groups was carried out through covariance analysis (ANCOVA). Meanwhile, qualitative data were analyzed based on the results of observations made after the treatment was applied, and the results of questionnaires. In this case, the condition and situation of the class during the learning process takes place, the interactions, motivations, attitudes, and interests of students in conducting the exercises and communicative activities are analyzed to determine the effectiveness of the learning model applied. Besides that, to find out the problems faced by students during the teaching and learning process, which causes students to not be able to improve their communicative competence. Therefore, there are a number of things discussed in this section.

\section{A. Result of the Pretest}

There are 15 topics discussed in the English language lecture in Tourism in semester 4 and each topic consists of two meeting sessions in a week. 3 topics selected for integrated learning. Learning is done 3 weeks with 2 meeting sessions each week. Before students receive treatment, the experimental and control groups are taught by conventional methods for one week or two meeting sessions. After the teaching and learning process is carried out, the pretest (test 1) is given to the two groups in the following week to ensure that the subject of this study is the communicative competence of students at the same level. The pretest results show that the average value is very similar as seen in table 1 . These results are calculated through Independent Samples Test (t-test), which is calculated at the level of $p<.05$ in the scores for the two groups $[\mathrm{t}=-.117, \mathrm{p}=.908]$.

TABLE I.

RESULTS OF T-TEST CALCULATIONS FOR THE LEVEL OF GROUP EQUALITY

\begin{tabular}{|c|c|c|c|c|c|c|}
\hline Method & Group & Number & Means & St. deviation & $\mathrm{t}$ table & Sig. $(2$ tailed $)$ \\
\hline Konventional & Control & 31 & 55.4393 & 6.34 & \multirow[t]{2}{*}{.117} & \multirow[t]{2}{*}{.908} \\
\hline Konventional & Experiment & 30 & 55.2609 & 5.26 & & \\
\hline
\end{tabular}

Based on the table above, the mean score of the student pretest is 55.44 in the control group and 55.26 in the experimental group. This average score is categorized as low, besides that students also become unfocused, less enthusiastic, and often others during the teaching and learning process.

\section{B. Result of the Treatments}

Starting from the results of observations on learning at the beginning of the study and giving pretest, the research continues with the treatment. In the planning step, the researcher focuses on efforts to increase the communicative competence of students through integrated learning in the experimental group. Therefore, planning learning scenarios and instruments is prepared before the action is given. After taking action in 3 learning cycles, this section discusses the results of each learning cycle. There are 15 topics discussed in the semester lecture plan and each topic consists of two weekly meeting sessions. Each meeting session was given an action in the form of practice (practice) and communicative activities (communicative activities) in each topic discussed. Starting from the results of observations 
on learning in the first week, the research begins with the first cycle. In the planning stage, research begins with preparing scenarios and learning instruments with topics of discussion giving information about attractions. The next step is giving action with brainstorming, pair work, and group discussions. All student learning activities are recorded on observation sheets and diaries. At the end of the meeting session, a test to measure student communicative competence was given.

The average value of the test results achieved by students in cycle 1 is 63.05 . These results indicate an increase in learning outcomes when compared with the pretest results of 55.26. Although student achievement in this cycle is higher than pretest, but based on observations throughout this cycle it was found that students still felt less confident and students who were slow also found themselves still having difficulty adjusting to other friends in group discussions. Knowing the weaknesses in cycle 1, it was reflected by the conclusion that students need facilitation during the exploration process which can reduce the factors that cause them to be less than optimal in learning, such as learning security that is not conducive. Therefore, business games and role-play are considered in giving action to cycle 2.

Learning cycle 2 is done in the third week and the topic of the discussion is to give directions to a place and a simple explanation of tourist objects (simple explaination on places of interest). Basically, the steps carried out in cycle 2 are the same as in the previous cycle, which begins with the preparation of learning scenarios where the provision of action is facilitated with business games and role-play in training and communicative activities. At the observation stage of this cycle, students begin to feel comfortable, become more active in participating in group discussions and they are interested in doing exercises and communicative activities facilitated by business games and role-play. However, there were some students who often borrowed the work of their friends in their respective groups before making a presentation. This problem is identified as a short-term learning utility. After reflecting on this problem, it is anticipated by facilitating exercises and communicative actions using techniques in the form of web-based project tasks (WebQuest) and problem solving (problem solving) in cycle 3 learning.

Learning cycle 3 was conducted in the fourth week which began with instructions in class about the WebQuest application through e-learning learning. After students are divided into small groups, namely 4-5 groups then they register in the Edmodo electronic learning application portal. Then students can access the WebQuest project assignments with the topic of optional tour selling. In this case the entire learning process is carried out interactively between lecturers and students online. In the second session of the fourth week of the group discussion about the tasks of the WebQuest project and also problem-solving techniques were carried out. As a reflection of cycle 3, students become very motivated in learning English. However, this study only consisted of three learning cycles so the research was stopped.

After giving the action to the three learning cycles, the fifth week posttest (test 2 ) to measure the communicative competence of students was given to both groups both experimental and control groups. The communicative competency test is in the form of speaking test which covers a series of situations in the context of travel business, such as inquiry and reservation, simple description on places of interest, and selling optional tours. The mean score in the posttest achieved by students in the control group was 63.05 and 84.43 in the experimental group. To answer the question of the first problem formulation (Is there a significant increase in the communicative competency and experimental group posttest scores?), Then the descriptive analysis and pairs of t-test sample pairs were used to determine statistically significant differences in the results of posttest in the two groups of students. The following table 2 shows the results of the paired sample t test, calculating the value of the communicative competence of students in the control group.

TABLE II

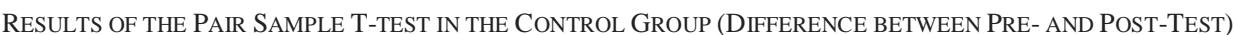

\begin{tabular}{llllllll}
\hline Group & Variable & Test & Number & Means & St. Deviation & t table & Sig. (2- tailed) \\
\hline Control & Communicative & Pre & 31 & 55.4393 & 5.71849 & \multirow{2}{*}{$-000^{* *}$} \\
& Competence & Pos & 31 & 63.0536 & 6.69209 & -47 \\
\hline$* *$ level of significance 05 & & & & &
\end{tabular}

Table 2 shows the communicative competence of students in the control group significantly increasing [t $=-6,932$, $p$ $=.000]$. There is a significant difference between the performance of students on instructions before giving pre- and post-test at the level of $\mathrm{p}<.01$. This result can be caused by the exposure of explicit grammatical rules that are more intensive than learning before giving pretest, so that students are better prepared to do the exercises and practice communicative activities. Figure 1 below shows the average score obtained by the control group in the pre- and tests. 


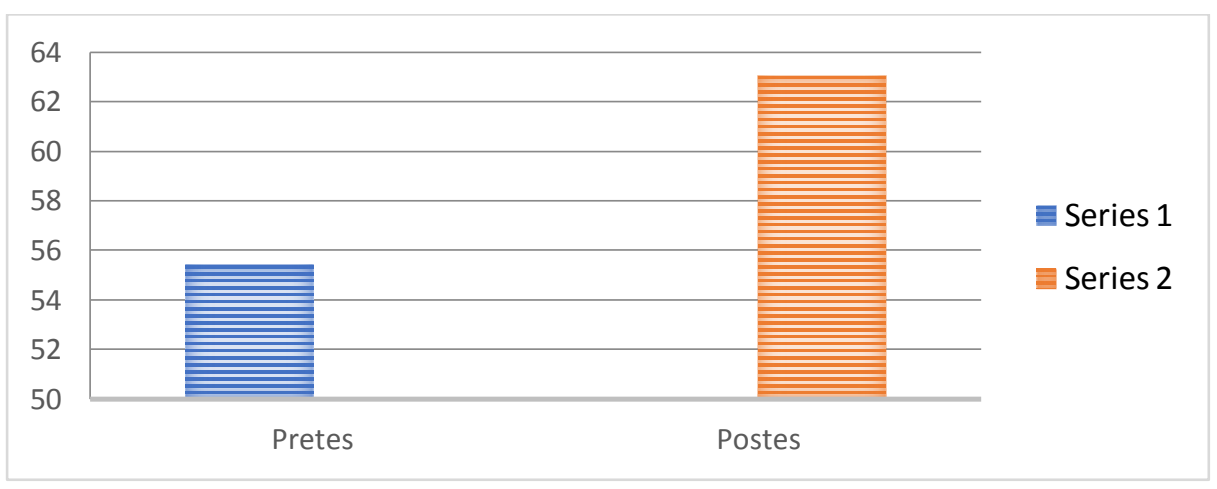

Figure 1. Average Group Communicative Competence Score Control on Pre- and Post-Tests

In the experimental group, the following table 3 shows the results of the paired sample $t$ test calculating the value of the communicative competence of students in the experimental group.

TABLE III

Results of PAIR TEST SAMPLE COUNTS T On EXPERIMENT GRoup (DIFFERENCE BETweEn PRE- AND POST-TEST)

\begin{tabular}{|c|c|c|c|c|c|c|c|}
\hline Group & Variable & Test & Number & Means & St. Deviation & t-table & Sig. (2- tailed) \\
\hline Experiment & $\begin{array}{l}\text { Communicative } \\
\text { Competence }\end{array}$ & $\begin{array}{l}\text { Pre } \\
\text { Post }\end{array}$ & $\begin{array}{l}30 \\
30\end{array}$ & $\begin{array}{l}55.2609 \\
84.4348\end{array}$ & $\begin{array}{l}5.06294 \\
4.64979\end{array}$ & -23.485 & $.000 * *$ \\
\hline
\end{tabular}

**level of significance .05

Table 3 shows that the communicative competence of students in the experimental group increased significantly [ $\mathrm{t}=-$ $25,185, \mathrm{p}=.000]$. This result is due to the practice and practice of English in intense practice and communicative activities, so that the average margin between pretest and posttest is higher in the experimental group than in the control group. The overall appearance of the results above from the experimental group can be seen below in Figure 2 .

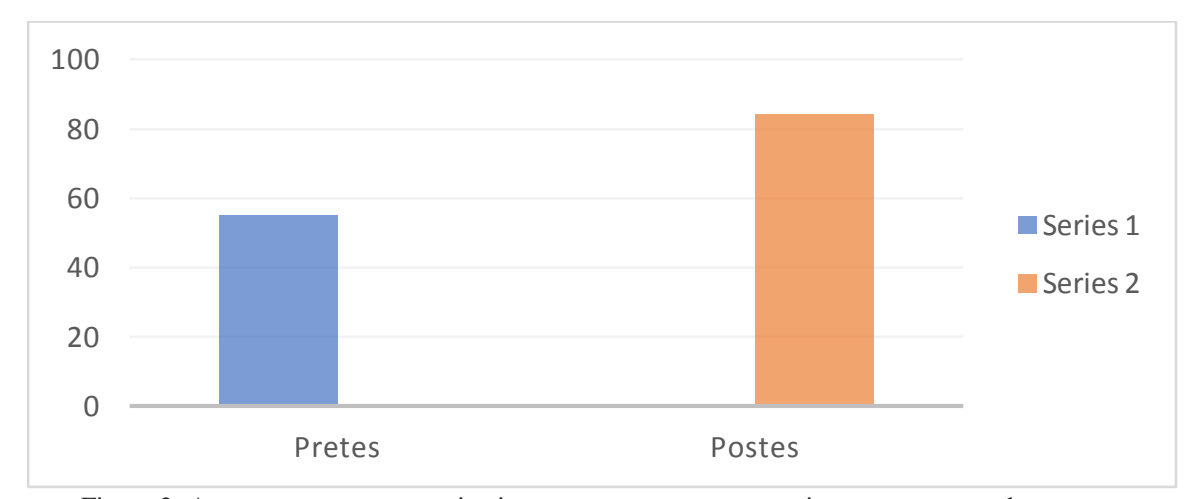

Figure 2. Average group communicative competence score experiments on pre- and post-tests

Results from both groups showed that there was a significant increase in students' speaking performance after receiving treatment. To find out how far the effect of the treatment is specifically to answer the second problem formulation (Is there a significant difference between the control and experimental groups in the posttest?), Covariance analysis (ANCOVA) is used by referring to the acquisition of the pretest score.

TABLE IV

ANCOVA TEST FOR CONTROL GROUPS AND EXPERIMENTS OF POST-TEST RESUlTS ON THE EFFECTS OF PRETENSIONS

\begin{tabular}{llllll}
\hline Method & Group & No & Means & St. deviasi & F \\
\hline Konventional & Control & 31 & 63.0536 & 6.69209 & 90.888 \\
\hline Inductive & Experiment & 30 & 84.4248 & 4.64979 & \\
\hline
\end{tabular}

Level of significance $.05^{* *}$

Table 4 shows that there were significant differences between the experimental and control groups in the posttest that controlled the pre-test score $[\mathrm{F}=24,286, \mathrm{p}=0,000]$ at level $\mathrm{p}<.01$. A very significant difference in the communicative competence of students reinforces the results of the analysis that inductive learning methods using authentic material can improve students' communicative competencies. Figure 3 below shows the difference in posttest mean scores of the two groups. 


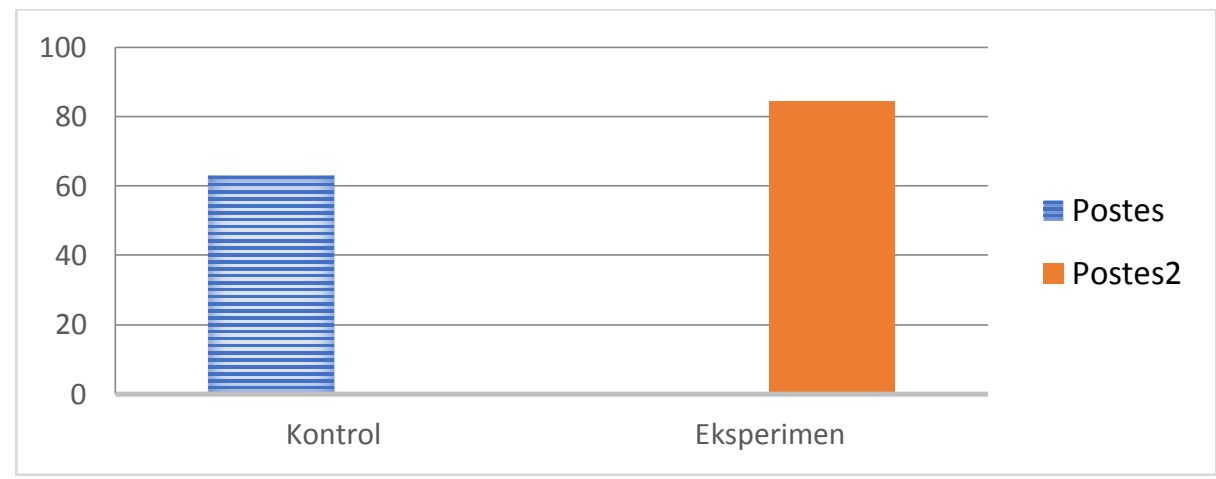

Figure 3. Average Group Communicative Competence Score Controls and Experiments on Postest

The figure shows that the mean score of the experimental group is higher than the control group in the posttest. This means that there is a significant difference between the application of deductive conventional teaching methods, namely presentation, training, communicative activities and inductive methods using authentic material embeded on conventional modified learning models, namely communicative activity, practice, presentation. The students' response to the application of learning with inductive methods in the Tourism English course showed positive results. Evidence of this statement can be seen from the results of questionnaire entries in each learning cycle. In cycle 1 there were $22 \%$ of students saying that they were very happy and 75\% said they were happy, and 3\% said that they were happy or unhappy, when they were asked about feelings and interests in learning English through integrated learning as shown in figure 3 below.

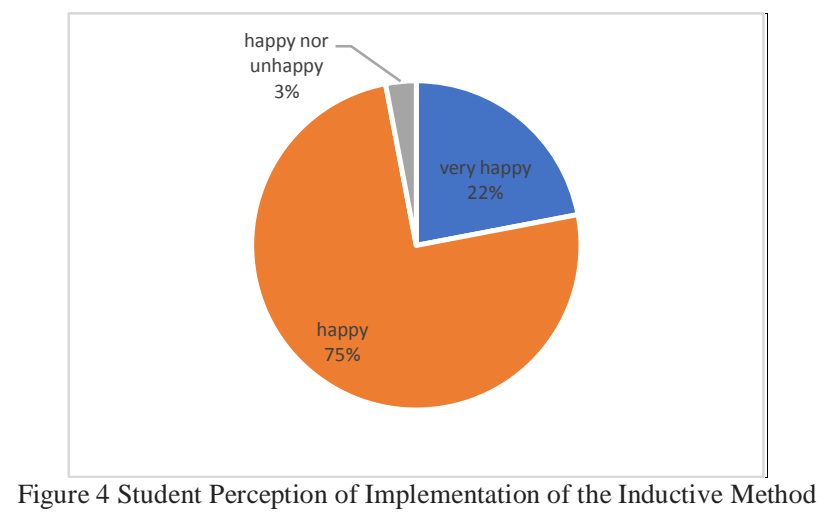

Students' positive perceptions of the application of inductive learning methods using authentic material are shown through the active participation of students in class interactions. However, there are some problems faced by students during the teaching and learning process, such as some students feel less confident in communicating using English because they are afraid of making mistakes in grammar and pronunciation, vocabulary and the use of limited expressions in producing speech, it is difficult to understand greetings from other students during the presentation. However, most students said that integrated learning can minimize the problems faced by these students, because of the facilitation of communicative exercises and activities by group discussion techniques, spouse work, business games, role playing, web-based project assignments, and problem solving in problem solving is done interestingly, so that it can eliminate negative factors in the learning process, such as boredom, hesitation and fear in learning.

\section{DISCUSSION}

The results of the study show that the inductive method using authentic material in learning English in Tourism has a very significant influence on students' communicative English competence. This was evident after classroom action research was conducted in three learning cycles for the experimental group. After giving action to each learning cycle, namely cycle 1 is facilitated by brainstorming, pairwork, and group discussion, cycle 2 with business games and roleplay, and cycle 3 with WebQuest and problem solving. Significantly increasing the English competence of students is also seen in the comparison of mean scores between pretest and posttest.

This increase was also supported by an increase in motivation and interest in learning as indicated by the results of filling out questionnaires. The questionnaire is formulated based on 3 main indicators, namely (1) effectiveness in the learning process both in offline and online activities; (2) the concept of learning based on the WebQuest project on cycle 3 learning; (3) student achievement in pre and posttest. In general, students have high interest and motivation to learn to do exercises and communicative activities in each learning cycle. In this case, the scaffolded and blended learning techniques are two key words for the success of student learning achievement. With scaffolding techniques 
(Ginaya et al., 2018), students get direction about the rules and principles of grammatical systems, treasury and word selection to create a sentence context. This direction is designed in such a way as a scaffold technique as temporary support for concrete in a building construction and when the concrete is considered strong enough, the scaffolding will slowly be removed, as well as the rules and principles learning temporary assistance is provided to maximize the prerequisite knowledge of students to get understanding of the rules of the language and then slowly and surely students are given the opportunity to work on their own both exercises and communicative activities. While blended learning (Ginaya et al., 2018) was given in cycle 3 through the task of the WebQuest project by utilizing communication and information technology that strengthens face-to-face learning in the classroom. Students are eager to work online to get extensive information, some current issues, and knowledge accessed via the internet and the web in the context of project assignments based on the topics discussed in cycle 3 .

The student's perception of learning that can be categorized as blended learning is very positive where students are very satisfied with this web-based learning technique. This supports the findings of Ginaya, et al. (2018), which examined the effect of blended learning on the speaking ability of 3rd semester students in the Business Study Program in Bali State Polytechnic Travel. This study revealed that the task of the WebQuest project as a learning method through the use of technology to strengthen conventional learning can significantly improve students' speaking abilities. The web-based project or WebQuest assignments strongly support productive skills speaking by students because the project integrates several advantages of language learning, such as analysis, synthesis, evaluation, assessment, problem solving and student creativity.

In addition, very lively classroom interactions with the learning techniques from brainstorming to problem solving make students interact optimally as in problem solving techniques students try to get better solutions as a problemsolving effort. These communicative exercises and activities aim to stimulate student-language creativity. In this case, student participation in the teaching and learning process increases well. This also means that students feel fun learning and they are encouraged to work hard by maximizing their potential to communicate in English. Therefore, the communicative competence of students increases significantly as shown in the posttest results. In addition, students get important input on the use of English from a variety of sources both online and offline in making training assignments and communicative activities that greatly help students deal with real situations they might face in the future.

Conversely, conventional learning in the control group is very inadequate where the instructions received by students are very monotonous, so they cannot perform optimally during the teaching and learning process. As a result, motivation and interest in learning is low, resulting in low learning participation as well. On the other hand, through scaffolding and web exploration techniques, students in the experimental group are guided to explore previously selected quantity and relevant web material and describe the quality for a learning content. Students browse the online site as a learning repertoire (Laborda, 2009). In other words, web material in the WebQuest assignment project provides a knowledge as a language input that Doughty and Long (2002) describe as linguistic complexity, quality, quantity, variation, authenticity, and relevance of the learning material they obtain when they surf the internet. Therefore, exposure to rich, relevant, and complex language input is a scientific finding as to why students in the experimental group are far superior to students in the control group in terms of the level of communicative competence.

\section{CONCLUSION}

Based on the findings and discussion previously stated, it can be concluded that the implementation of authentic material-based inductive methods towards improving communicative competence of students can create innovative, creative, collaborative, cooperative learning through facilitation of learning that is capable of generating critical thinking, supporting each other (sharing ideas), problem solving skills, the ability to negotiate (negotiating), provide service orientation, and have cognitive rigidity with a high level of critical thinking (high order critical thinking skills or HOTS). In essence, the learning process boils down to the development of the concept of green \& sustainable tourism as a theme of superior research which is described as one of the related fields, namely communication \& information technology and green human resources. Inductive learning using authentic material will implicitly support the achievement of the objectives of the above themes by increasing the sources and competitiveness of lecturers and the quality of English learning programs. Quality services will have a positive effect on stakeholders, which will eventually lead to the realization of green \& sustainable tourism, the popularity of institutions, and the welfare of society in the end.

Considering the conclusions above, the inductive method using authentic material in modified-conventional learning is an innovative learning model as an alternative to learning English. In this case, the lecturer should actively facilitate scaffolded and blended learning techniques to make students motivated, engaged, active, and creative in doing exercises and communicative activities so learning English becomes fun. In addition, the learning process through training and communicative activities can evoke critical thinking skills of students, such as comparing, classifying, inducing, inferring, analyzing errors, building support, abstraction, analyzing perspectives. Therefore, the creativity of lecturers in designing fun and dynamic exercises and communicative activities can stimulate students' interest in learning and motivation. 


\section{ACKNOWLEDGEMENTS}

The author expresses his gratitude to the parties who have contributed and encouraged the completion of this article as follows.

1. Kementerian Riset dan Technologi Pendidikan Tinggi or the Ministry of Technology and Research of Higher Education who funded the authors' research in the scheme of Penelitian Terapan Unggulan Perguruan Tinggi (PTUPT) or the Excellence of Higher College Applied-Research 2019.

2. I Ketut Suarta and A.A.A. N. Harmini as Chair of the Department and Tourism Study Program, the Bali State Polytechnic who gives author permission to conduct research in the Tourism Business Study Program.

3. 4th Semester Student Tourism Business Travel Program Academic Year 2019/2020.

4. Prof. Dr. Ni Putu Kerti Nitiasih, MA who validates research instruments in the form of tests.

\section{REFERENCES}

[1] Al Azri, R. H., \& Al-Rashdi, M. H. (2014). The effect of using authentic materials in teaching. International journal of scientific \& technology research, 3(10), 249-254.

[2] Allehyani, B., Burnapp, D., \& Wilson, J. (2017). A comparison of teaching materials (school textbooks vs authentic materials) from the perspective of English teachers and educational supervisors in Saudi Arabia. International Journal of English Language and Linguistics Research, 5(2), 1-14.

[3] Bagarić, V., \& Dịigunović, J. M. (2007). Defining communicative competence. Metodika, 8(1), 94-103.

[4] Balım, A. G. (2009). The Effects of Discovery Learning on Students' Success and Inquiry Learning Skills. Eurasian Journal of Educational Research (EJER), (35), 1-20.

[5] Belaid, A. M., \& Murray, L. (2015). Using authentic materials in the foreign language classrooms: Teacher attitudes and perceptions in Libyan Universities. International Journal of Learning and Development, 5(3), 25-37.

[6] Carmona Carmona, M. K. (2015). The use of authentic material to develop reading skills in English language learners in the tenth grade at Ángel Modesto Paredes High School (Bachelor's thesis).

[7] Castillo Losada, C. A., Insuasty, E. A., Osorio, J., \& Fernanda, M. (2017). The Impact of Authentic Materials and Tasks on Students' Communicative Competence at a Colombian Language School. Profile Issues in TeachersProfessional Development, 19(1), 89-104.

[8] Celce-Murcia, M. (2008). Rethinking the role of communicative competence in language teaching. In Intercultural language use and language learning (pp. 41-57). Springer, Dordrecht.

[9] Creswell, J. W., \& Creswell, J. D. (2017). Research design: Qualitative, quantitative, and mixed methods approaches. Sage publications.

[10] Davtyan, R. (2014, April). Contextual learning. In ASEE 2014 Zone I Conference, April (pp. 3-5).

[11] Day, R. R. (2004). A critical look at authentic materials. The Journal of AsiaTEFL, 1(1), 101-114.

[12] Dorda, S. V., \& Klochko, L. I. (2008). The Role of Materials in Teaching ESP. ВICНИК, 42.

[13] Doughty, C., \& Long, M. H. (2002). Creating the optimal learning environment in a DL language course. In Title VI conference on distance learning of the less commonly taught languages. Retrieve January (Vol. 20, p. 2003).

[14] Dudeney, G., \& Hockly, N. (2012). ICT in ELT: how did we get here and where are we going?. ELT journal, 66(4), 533-542.

[15] Eison, J. (2010). Using active learning instructional strategies to create excitement and enhance learning. Jurnal Pendidikantentang Strategi Pembelajaran Aktif (Active Learning) Books, 2(1), 1-10.

[16] Ginaya, G., Aryana, I. N. R., \& Somawati, N. P. (2018). Improving Students' Speaking Ability through Scaffolding Technique. Soshum: Jurnal Sosial dan Humaniora, 8(1), 72-85.

[17] Ginaya, G. (2018). The Balinese calendar system: From its epistemological perspective to axiological practices. International Journal of Linguistics, Literature and Culture (IJLLC), 4(3), 24-37.

[18] Ginaya, G., Rejeki, I. N. M., \& Astuti, N. N. S. (2018). The effects of blended learning to students' speaking ability. International Journal of Linguistics, Literature and Culture (IJLLC), 4(3), 1-14.

[19] Glaser, K. (2014). Inductive or deductive?: The impact of method of instruction on the acquisition of pragmatic competence in EFL. Cambrige: Cambridge Scholars Publishing.

[20] Ghanbari, N., Esmaili, F., \& Shamsaddini, M. R. (2015). The effect of using authentic materials on Iranian EFL learners' vocabulary learning. Theory and Practice in Language Studies, 5(12), 2459.

[21] Kemmis, S., McTaggart, R., \& Nixon, R. (2013). The action research planner: Doing critical participatory action research. Singapore: Springer Science \& Business Media.

[22] Kilickaya, F. (2004). Authentic materials and cultural content in EFL classrooms. Online Submission, 10(7), 1-5.

[23] Kim, D. K. (2000). A Qualitative Approach to the Authenticity in the Foreign Language Classroom: A Study of University Students Learning English in Korea. Texas Papers in Foreign Language Education, 5(1), 189-205.

[24] Laborda, J. G. (2009). Using webquests for oral communication in English as a foreign language for Tourism Studies. Journal of Educational Technology \& Society, 12(1), 258-270.

[25] McDonough, J., \& Shaw, C. (2012). Materials and Methods in ELT. John Wiley \& Sons. West Sussex: John Wiley \& Sons Ltd.

[26] Polio, C. (2014). Using authentic materials in the beginning language classroom. Center for Language Education and Research, $18(1), 1-5$.

[27] Prince, M. J., \& Felder, R. M. (2006). Inductive teaching and learning methods: Definitions, comparisons, and research bases. Journal of engineering education, 95(2), 123-138.

[28] Prince, M., \& Felder, R. (2007). The many faces of inductive teaching and learning. Journal of college science teaching, 36(5), 14-20.

[29] Day, R. R. (2004). A critical look at authentic materials. The Journal of AsiaTEFL, 1(1), 101-114. 
[30] Richards, J. C., \& Rodgers, T. S. (2014). Approaches and methods in language teaching. Cambridge: Cambridge university press.

[31] Rodríguez González et al. (2016). "Review of Problem-Based Learning applied to Engineering". EduRe Journal Vol. 3 № 1 (2016): 14-31. Retrived January 10, 2018 from http://edure.org/EdureJournal.htm.

[32] Saumell, V. (2012). Guided Discovery for Language Instruction: A Framework for Implementation at All Levels. Buenos Aires: Person.

[33] Slavin, R. E. (2010). Co-operative learning: what makes group-work work. The nature of learning: Using research to inspire practice, 161-178.

[34] Syarkawi, M. (2015). Menggagas Konsep "Green Human Resource”. Retrieved January 15, 2018 from http://harian.analisadaily.com/.

[35] Tomlinson, B. (2012). Materials development for language learning and teaching. Language teaching, 45(2), 143-179.

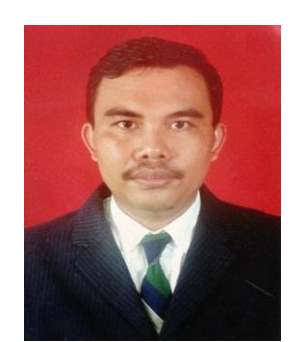

Gede Ginaya was born in Buleleng, Bali, Indonesia on $19^{\text {th }}$ September 1966. He is a permanent lecturer of English at Tourism Department, Politeknik Negeri Bali (PNB), Bali, Indonesia. He received a bachelor's degree in English language teaching from The Faculty of Education and Teacher Training Udayana University, Bali, Indonesia (Currently is UNDIKSHA Singaraja) in 1992 and a master's degree in cultural studies from the Faculty of Arts, Udayana University, Bali, Indonesia in 2010.

He has been assigned to teach English for Tourism in the three study programs of Tourism Department, Politeknik Negeri Bali, Indonesia. His research interests include classroom-action research, cultural studies, and tourism and have been published in several journals. His Email address: ginaya@pnb.ac.id

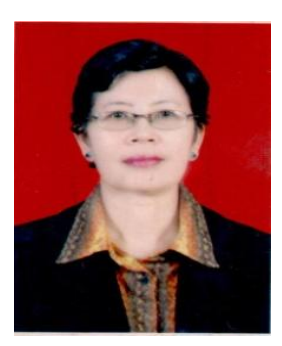

Ni Putu Somawati was born on $27^{\text {th }}$ of May 1963 in Denpasar, Bali, Indonesia. She is a permanent lecturer of English at Tourism Department, Politeknik Negeri Bali (PNB), Bali, Indonesia. She received a bachelor's degree in English Department, faculty of letters, Udayana University, Bali, Indonesia in 1987. She continued to master program in management and was awarded Magister Manajemen (MM) in Udayana University, Bali, Indonesia in 2005.

Her research interests include development tourism, English literature, English language teaching. Her Email address: putusomawati@pnb.ac.id

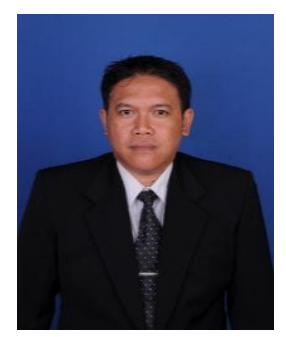

I Nyoman Rajin Aryana was born in Buleleng, Bali, Indonesia on $4^{\text {th }}$ July 1975 . He is a permanent lecturer of English at Tourism Department, Politeknik Negeri Bali (PNB), Bali, Indonesia. He received a bachelor's degree in English language teaching from The School of Teacher Training and Education, (STKIP) Singaraja, Bali, Indonesia (Currently is UNDIKSHA Singaraja) in 1999 and a master degree in Linguistic majoring at Translation studies from the Faculty of Arts, Udayana University, Bali, Indonesia in 2014.

He has been assigned to teach English for Tourism in the two study programs of Tourism Department, Politeknik Negeri Bali, Indonesia such as Tour and Travel and Tourism Business Management Study Program. His research interests include classroom-action research, teaching learning activity and tourism, and have been published in several journals. His Email address: nyomanrajinaryana@pnb.ac.id

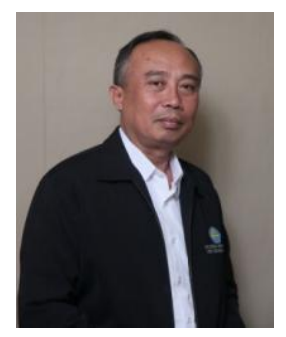

I Made Ardana Putra was born in Amlapura, Bali, Indonesia on $19^{\text {th }}$ September 1959. He is a permanent lecturer of English at Business Administration Department, Politeknik Negeri Bali (PNB), Bali, Indonesia. He received a bachelor's degree in English Department Faculty of Letter Udayana University, Bali, Indonesia in 1986 and a master's degree in Cultural Studies from the Faculty of Arts, Udayana University, Bali, Indonesia in 2002.

He has been assigned to teach English for International Business Management in the four study programs of Business Administration Department, Politeknik Negeri Bali, Indonesia. His research interests include classroom-action research, cultural studies, and tourism and have been published in several journals. His Email address: ardana_rena@pnb.ac.id 